\title{
Quantification of coral heat shock proteins from individual coral polyps
}

\author{
Erin Bromage ${ }^{1,3, *, * *}$, Lawrence Carpenter $^{2,4, * *}$, Stephen Kaattari $^{1}$, Mark Patterson ${ }^{2}$ \\ ${ }^{1}$ Department of Environmental and Aquatic Animal Health, and ${ }^{2}$ Department of Biological Sciences, Virginia Institute of \\ Marine Science, College of William \& Mary, Gloucester Point, Virginia 23062, USA \\ ${ }^{3}$ Department of Biology, University of Massachusetts Dartmouth, 285 Old Westport Road, North Dartmouth, \\ Massachusetts 02747, USA
}

${ }^{4}$ Applied Ocean Physics \& Engineering Department, Woods Hole Oceanographic Institution, Deep Submergence Laboratory, MS\#7, 266 Woods Hole Road, Woods Hole, Massachusetts 02543, USA

\begin{abstract}
The induction and regulation of heat shock proteins (hsps) is a significant defense mechanism that can preserve metabolic function and foster recovery from short-term stress events. Present coral sampling methodologies that involve hsp analysis often require the harvesting of large samples of live coral colonies that may already be stressed or in poor health. In the present study, 3 novel protocols were developed to: (1) extract single coral polyps, minimizing colony trauma; (2) purify protein from single coral polyps (approximately $12 \mathrm{~mm}^{3}$ ); and (3) develop a more sensitive protein quantification method. The preliminary testing of 5 separate protein preparation methods resulted in a range of total protein yields from 47 to $77 \mu \mathrm{g}$ coral polyp $\mathrm{p}^{-1}$. The optimized methods were able to recover, on average, $44 \pm 12 \mu \mathrm{g}$ protein $\operatorname{polyp}^{-1}(\mathrm{n}=20)$. Subsequent SDS-PAGE and immunoblotting analysis of single coral polyps resolved as little as $87 \mathrm{pg}$ hsp70 coral polyp ${ }^{-1}$. This minimally invasive sampling protocol reduces coral damage and, thus, reduces stress and diseases caused by sampling.
\end{abstract}

KEY WORDS: Coral $\cdot$ Heat stock proteins $\cdot$ hsp $\cdot$ Polyp $\cdot$ Proteins $\cdot$ Stress

\section{INTRODUCTION}

It is widely understood that coral reefs are in a state of global decline (Wilkinson et al. 1999, Jackson et al. 2001, Gardner et al. 2003, Hoegh-Guldberg 2003, Hughes et al. 2003, Pandolfi et al. 2003, Carpenter et al. 2008). Coral reef systems that endure chronic environmental and anthropogenic disturbances can exhibit a range of deleterious impacts, for example, depressed reproductive effort and growth rates, elevated frequency and severity of diseases, and mass mortalities (Hoegh-Guldberg 1999, Nystrom et al. 2000, Knowlton 2001). Coral biologists also confront a crucial dilemma as they must often destroy corals simply to study the animals (Yamashiro et al. 1999). Thus, there is a critical need to develop techniques that can minimize the impact of sampling on these delicate systems.
The production of heat shock proteins (hsps) is a commonly used biomarker in coral health assessment (Sharp et al. 1994, Bythell et al. 1995, Downs et al. 2000). During 'normal' cellular functions, hsps fulfill several roles, including chaperone activities, translocation and the oligomerization of proteins (Buckley \& Hofmann 2002, Hofmann 2005). These molecular chaperones include a range of low molecular weight proteins, i.e. hsc70, hsp70 and hsp90, and appear to assist in the folding of newly synthesized proteins, ensuring the maintenance of tertiary structures (Buckley \& Hofmann 2002, Hofmann 2005). During stress events, hsps also appear to have a critical role in protein stabilization via the inhibition of nonspecific interactions between and within constituent proteins, i.e. a pro-active, house-keeping mechanism and that of a stress response (Lindquist 1986, Ellis 1996). These 
proteins may also indicate an organism's potential to adapt to future stressors, as has been observed by the delayed onset of stress protein synthesis due to a previous stressor (Buckley \& Hofmann 2002, Hofmann 2005).

Heat shock protein regulation and synthesis have been well documented for a number of cnidarians. Heat shock protein 70 (hsp70) has been resolved in the coral Goniopora djiboutiensis (Sharp et al. 1994), as well as in the anemone Anemonia viridis, which produced a number of different hsp isoforms when exposed to elevated temperatures (Miller et al. 1992). A range of hsps was detected while resolving the very abundant $33 \mathrm{kDa}$ protein from the sea anemone A. viridis, as well as in the tropical corals G. djiboutiensis, G. pandoraensis and G. stokesi (Bythell et al. 1995), in addition to thermal experiments on the sea anemone Aiptasia pallida and the Caribbean reef coral Montastraea faveolata (Black et al. 1995).

In order to study coral hsps, current methodologies require the collection of coral tissue. Collection of coral tissue for hsp analysis currently requires the use of a hammer and chisel (Miller \& Ayre 2004), a steel hole punch (Toller et al. 2001) and coring (Rowan et al. 1997). The amount of coral tissue collected for hsp analysis has also varied greatly between studies (Table 1). For example, Brown et al. (2002) collected $25 \mathrm{~mm}$ wide cores $\left(500 \mathrm{~mm}^{2}\right)$, Black et al. (1995) collected $50 \mathrm{~mm}$ cores $\left(2000 \mathrm{~mm}^{2}\right)$, while Downs et al. (2000) utilized $2500 \mathrm{~mm}^{2}$ of coral tissue for their study. These techniques, while meeting their goal of collecting coral tissue, are not optimal, as they may render the remaining colony susceptible to disease or result in additional loss of the soft tissue bordering the fragmented zones. It also must be noted that the majority of these studies used the collected explants in laboratory stress studies, rather than determining the health of the coral in situ.

A possible cause for the lack of in situ assessment studies on coral hsps is the large amount of processing required for each sample prior to assessment. Proteases can degrade target proteins prior to assessment, and excessive $\mathrm{CaCO}_{3}$ from the coral skeleton can interfere with processing. High levels of polysaccharides (Ducklow \& Mitchell 1979, Krupp 1985) and lipids (Achituv et al. 1994, Yamashiro et al. 1999, Oku et al. 2003) found in coral tissue and mucus also need to be removed, as they block the pores of gels used in sodium dodecyl sulfate-polyacrylamide gel electrophoresis (SDS-PAGE) (Saravanan \& Rose 2004, Carpentier et al. 2005), resulting in lane smearing and non-specific binding. Thus, removing (via processing) or neutralizing (e.g. freezing and protease inhibitors) these contaminants while in the field, from such large coral samples, would be difficult and prohibitively expensive.

In the present study, we describe techniques for the collection, processing, analysis and quantification of hsp content from single coral polyps. The employment

Table 1. Comparison of coral sample sizes and biomarkers studied. Hsp: heat shock proteins

\begin{tabular}{|c|c|c|c|c|}
\hline Coral field collection & $\begin{array}{l}\text { Quantity and type } \\
\text { of coral tissue removed }\end{array}$ & Subject studied & Biomarker studied & Source \\
\hline $3 \mathrm{~mm}$ & $\begin{array}{l}12 \mathrm{~mm}^{2} \\
\text { (soft tissue) }\end{array}$ & $\begin{array}{l}\text { Coral polyp sampling, } \\
\text { protein purification and } \\
\text { quantification development }\end{array}$ & Hsps $70 \& 90$ & $\begin{array}{l}\text { Present } \\
\text { study }\end{array}$ \\
\hline $25 \mathrm{~mm}$ cores & $\begin{array}{l}25 \mathrm{~mm} \\
\text { cores }\end{array}$ & $\begin{array}{l}\text { Cellular diagnostics and } \\
\text { coral health: declining coral } \\
\text { health in the Florida Keys }\end{array}$ & $\begin{array}{l}\text { A range of physio- } \\
\text { logical biomarkers, } \\
\text { including hsps } 60 \& 70\end{array}$ & $\begin{array}{l}\text { Downs et al. } \\
(2005)\end{array}$ \\
\hline $30-50 \mathrm{~mm}^{2}$ & $10-30 \mathrm{~mm}^{2}$ & $\begin{array}{l}\text { Population recovery and } \\
\text { differential hsp expression } \\
\text { for the corals }\end{array}$ & Hsps $70 \& 90$ & $\begin{array}{l}\text { Robbart et al. } \\
(2004)\end{array}$ \\
\hline $25 \mathrm{~mm}$ cores & $\begin{array}{l}25 \mathrm{~mm} \\
\text { cores }\end{array}$ & $\begin{array}{l}\text { Exploring the basis of } \\
\text { thermo-tolerance in the reef } \\
\text { coral Goniastrea aspera }\end{array}$ & $\begin{array}{l}\text { A range of biomarkers } \\
\text { studied, including } \\
\text { hsps } 60 \& 70\end{array}$ & $\begin{array}{l}\text { Brown et al. } \\
(2002)\end{array}$ \\
\hline $\begin{array}{l}\text { Coral skirts, size } \\
\text { unspecified, but } \\
\text { fragments were then } \\
\text { cut into } 50 \mathrm{~mm}^{2}\end{array}$ & $50 \mathrm{~mm}^{2}$ & $\begin{array}{l}\text { A molecular biomarker system } \\
\text { for assessing the health of the } \\
\text { coral Montastraea faveolata } \\
\text { during heat stress }\end{array}$ & $\begin{array}{l}\text { A suite of molecular } \\
\text { and cellular } \\
\text { biomarkers, including } \\
\text { hsps } 60 \& 70\end{array}$ & $\begin{array}{l}\text { Downs et al. } \\
(2000)\end{array}$ \\
\hline $\begin{array}{l}\text { Samples consisted } \\
\text { of } \sim 50 \text { to } 80 \text { polyps }\end{array}$ & $\begin{array}{l}\text { Samples } \\
\text { consisted of } \sim 50 \text { to } \\
80 \text { polyps }\end{array}$ & $\begin{array}{l}\text { Hsp } 70 \text { expression in the } \\
\text { tropical reef coral Goniopora } \\
\text { djiboutiensis }\end{array}$ & Hsp70 & $\begin{array}{l}\text { Sharp et al. } \\
(1997)\end{array}$ \\
\hline $50 \mathrm{~mm}$ diameter cores & $\begin{array}{l}\text { Amount } \\
\text { unstated }\end{array}$ & $\begin{array}{l}\text { Hsp induction in Montastraea } \\
\text { faveolata and Aiptasia pallida } \\
\text { exposed to elevated temperatures }\end{array}$ & $\begin{array}{l}\text { Hsps } 95,90,78 \\
74,33,2,27\end{array}$ & $\begin{array}{l}\text { Black et al. } \\
\text { (1995) }\end{array}$ \\
\hline
\end{tabular}


of these minimally invasive techniques will allow time series analysis of single coral colonies from corals in the field and laboratory settings.

\section{MATERIALS AND METHODS}

Coral polyp sampling method. Coral samples were excised from colonies of Montastraea annularis with a hollow-point (4 mm i.d.) stainless steel spike. These sampling tools were assembled by embedding a Menuhin Kidney Biopsy Needle (Arista Surgical Supply Co.) into a predrilled hardwood handle. They proved sufficiently robust to withstand tip damage from the corals' underlying $\mathrm{CaCO}_{3}$ skeleton and were re-sharpened or replaced when required. Coral polyps were recovered by applying constant rotational pressure until the tip reached the underlying $\mathrm{CaCO}_{3}$ structure. The spike was then slowly withdrawn, and the polyp was transferred into a pre-labeled cryogenic Eppendorf centrifuge tube containing a cocktail of protease inhibitors (P8349, Sigma) to inhibit protein degradation, diluted to a volume ratio of $1: 100$ (inhibitor:sample). Samples were stored in liquid nitrogen until required.

Pooled polyp preparations. Five different protocols were assessed for their efficiency in protein recovery from polyp preparations.

Technique i: For the first technique, samples were processed according to the procedure of (Downs et al. 2000), with minor modifications for single polyps. Polyps $(n=5)$ were thawed and processed individually. The tissues were disrupted using repeated freezethaw cycles in liquid nitrogen, then homogenized in the Eppendorf tube using a Teflon pestle. Freshly prepared sample buffer (Downs et al. 2000) was then added, and the sample was heated to $95^{\circ} \mathrm{C}$ for 6 to 10 min with repeated mixing. Samples were then centrifuged at $13000 \times g$, at $4^{\circ} \mathrm{C}$, for $15 \mathrm{~min}$. The middle phase containing coral proteins was removed by inserting a needle through the Eppendorf wall to minimize the disturbance to the upper polysaccharide layer. Samples were then assayed in duplicate for total protein using the method of (Ghosh et al. 1988), with minor modifications. Briefly, $1 \mu$ volumes of sample, sample buffer and standard were spotted, in duplicate, onto Whatman (3M) filter paper, allowed to dry and then stained for $20 \mathrm{~min}$ in Coomassie blue (G250, Sigma). The filter paper was then de-stained in $50 \%$ methanol:10\% acetic acid (vol:vol), until there was no visible background. The paper was then dried at room temperature, and the individual sample spots were excised in discs of uniform size with a paper hole punch. Duplicate blanks containing no sample were also prepared to compensate for any remaining back- ground stain in the filter paper. Each stained spot was then eluted from the paper into $1 \mathrm{ml}$ of $1 \%$ SDS with agitation; $200 \mu \mathrm{l}$ of each replicate supernatant was subsequently transferred to a 96-well microtiter plate, and absorption was read at $595 \mathrm{~nm}$ using a microtiter plate spectrophotometer. The remaining samples were stored at $-20^{\circ} \mathrm{C}$ until required.

To accurately compare the 4 following polyp-processing methodologies, it was necessary to pool coral polyps together to remove individual polyp variation from the analysis. To achieve this, 20 individually sampled coral polyps were pooled together and $2 \mathrm{ml}$ of Laemmli reducing sample buffer (minus glycerol and bromophenol blue; Laemmli 1970) were added. The pooled polyps were ground for $1 \mathrm{~min}$ with an Eppendorf grinder (Kontes No. 749521-1500), then boiled for $5 \mathrm{~min}$ and ground for a further $30 \mathrm{~s}$. The polyp homogenate was spun for $10 \mathrm{~min}$ at $10000 \times g$, and the supernatant was removed and aliquoted into 20 samples (equating to 20 identical 1-coral-polyp-equivalent samples). The following 4 further methods of protein precipitation were tested on the mock 1-polyp samples $(n=5)$.

Technique ii: Ammonium sulfate: an equal volume of saturated ammonium sulfate was slowly added to the polyp homogenate and then rotated overnight at $4^{\circ} \mathrm{C}$.

Technique iii: Acetone: 4 vol of chilled acetone $\left(-20^{\circ} \mathrm{C}\right)$ was added to the polyp homogenate, vortexed and incubated overnight at $-20^{\circ} \mathrm{C}$.

Technique iv: Trichloroacetic acid + Deoxycholate (TCA + DOC): an equal volume of chilled $20 \%$ TCA containing $2 \%$ DOC was added to the polyp homogenate and incubated overnight at $-20^{\circ} \mathrm{C}$.

Technique v: TCA + DOC + Acetone + Beta-mercaptoethanol (2ME): 4 vol of acetone containing 15\% TCA $+1 \%$ DOC and $0.07 \% 2 \mathrm{ME}$ were added to the polyp homogenate, vortexed and incubated for $3 \mathrm{~h}$ at $-20^{\circ} \mathrm{C}$ (Table 2).

Following all incubations, the polyp homogenates were centrifuged at $15000 \times g$ for $30 \mathrm{~min}$; the supernatants were then removed from the pellets and discarded. Each pellet was then vortexed in $500 \mu \mathrm{l}$ of

Table 2. Handling time and recovery of total protein from single coral polyps using various techniques for processing. TCA: trichloroacetic acid; DOC: deoxycholate; 2ME: beta-mercaptoethanol

\begin{tabular}{|lcc|}
\hline Technique & $\begin{array}{c}\text { Preparation } \\
\text { time }\end{array}$ & $\begin{array}{c}\text { Protein yield }(\mu \mathrm{g}) \\
\text { per polyp }\end{array}$ \\
\hline (i) Downs & $2 \mathrm{~d}$ & $67 \pm 15$ \\
(ii) Ammonium sulfate & Overnight & $47 \pm 12$ \\
(iii) Acetone & Overnight & $62 \pm 6$ \\
(iv) TCA + DOC & Overnight & $56 \pm 13$ \\
(v) Acetone + TCA + & $5 \mathrm{~h}$ & $77 \pm 9$ \\
DOC + 2ME & & \\
\hline
\end{tabular}


ice-cold acetone containing $0.07 \% 2 \mathrm{ME}$ and centrifuged at $15000 \times g$. The supernatant was removed, and this process was then repeated 1 additional time. The pellet was allowed to air dry for $10 \mathrm{~min}$ at room temperature before being re-suspended in $25 \mu \mathrm{l}$ of $8 \mathrm{M}$ urea and then in $75 \mu \mathrm{l}$ of double-strength Laemmli sample buffer. A $6 \mu$ sample was drawn off for protein quantification, and the remaining solution was stored at $-20^{\circ} \mathrm{C}$ until required.

Total protein estimation. A new technique for protein estimation was developed to assess total coral protein preparations using a small sample volume $(2 \mu \mathrm{l})$, at low concentration $\left(<200 \mu \mathrm{g} \mathrm{ml}^{-1}\right)$, in the presence of Laemmli sample buffer, which can interfere with other protein quantification methods. This novel total protein estimation technique was required so that a consistent amount of protein could be loaded onto gels for quantification of hsps. Immobilon-FL (Millipore) was activated in $100 \%$ methanol and subsequently placed in ultrapure water for $5 \mathrm{~min}$. The activated membrane was dried briefly on filter paper to remove surface water and placed on a clean dry surface. Before the membrane dried, $2 \mu \mathrm{l}$ aliquots of each protein sample were added in duplicate to the membrane. For protein estimation, a series $(3.12,6.25,12.5$, $25,50,100,200,400,800,1600 \mathrm{ug} \mathrm{ml}^{-1}$ ) of acetoneprecipitated bovine serum albumin (BSA), in doublestrength Laemmli sample buffer, was added in $2 \mu \mathrm{lvol}-$ umes to the membrane. Following application of samples and standards, the membrane was allowed to air dry to promote protein adhesion. The membrane was subsequently reactivated in methanol, and washed 3 times ( 5 min each) in ultra-pure water. The blot was stained with freshly made Coomassie blue (G250, Sigma) for 1 min and then de-stained in the dark with multiple changes of de-stainer $(10 \%$ acetic acid, $50 \%$ methanol, $40 \%$ water), until the background was completely decolorized. The de-stained polyvinylidene difluoride (PVDF) was allowed to dry and was subsequently scanned on the Odyssey Infrared Imaging System (Li-COR Biosciences). Coomassie blue protein stain fluoresces in the near-infrared range, thus enabling protein detection and quantification via the $700 \mathrm{~nm}$ laser.

Electrophoresis and western blotting. To assess the efficiency of each protein preparation technique, $5 \mu \mathrm{g}$ of protein from each sample preparation method were added to a $10 \%$ SDS-PAGE gel (Harlow \& Lane 1988) and electrophoresed at $125 \mathrm{~V}$ until the dye front approached the bottom of the gel. The contents of the gel were transferred to PVDF (Immobilon-FL, Millipore) as per the manufacturer's instructions, and total protein was visualized by colloidal gold (BioRad). The resolution of protein bands was compared between each preparation technique.
The utility of various commercial anti-hsp antibodies, previously used for assessing hsp content in corals, was assessed with each of the polyp preparations. Five identical $10 \%$ SDS-PAGE gels were loaded with broad-range, pre-stained molecular weight markers (BioRad) and $10 \mathrm{ng}$ of hsp70, hsp 90 and hsc70 (SPA812, SPA-770, SPA-751, respectively, Stressgen Bioreagents) to serve as positive controls and calibrants for quantification on the gel. The remaining wells were loaded with $5 \mu \mathrm{g}$ of a coral polyp homogenate preparation (Technique v) from a heat-stressed coral. The proteins were electrophoresed at $125 \mathrm{~V}$ until the dye front reached the bottom of the gel. The contents of the gel were transferred to the membrane as per the manufacturer's instructions. The membranes were blocked with $3 \%$ casein for $1 \mathrm{~h}$, with shaking. The membranes were then incubated overnight at $4^{\circ} \mathrm{C}$, with $20 \mathrm{ml}$ of a $0.5 \mu \mathrm{g} \mathrm{ml}^{-1}$ solution of primary antibody (Table 3 ) washed 3 times with phosphate-buffered saline (PBS), then incubated for $1 \mathrm{~h}$ with the appropriate secondary antibody labeled with complementary dyes (IR 680 or IR 800) and washed again. The wet membranes were scanned on the Odyssey Infrared Imaging System in both the 700 and the $800 \mathrm{~nm}$ channel, giving rise to the red and green channel detection.

Total protein and hsp quantification. The Odyssey Infrared Imaging System was used for assessment of both hsp expression via western blotting and total protein analysis using Coommassie blue staining. For protein estimation, a logarithmic series of protein standards (3.12 to $1600 \mathrm{\mu g} \mathrm{ml}^{-1}$ ) was loaded onto the membrane and processed as described above. To assess the range of detection for western blotting, a series of hsp70 calibrant concentrations (10 pg to $100 \mathrm{ng}$ ) was loaded on a single SDS-PAGE gel and assessed via western blotting. Quantification of hsps in the polyp samples was achieved by comparing the scanned hsp intensity to the calibrant present on each

Table 3 . The 5 antibody systems tested for detection of heat shock proteins in coral polyps

\begin{tabular}{|ll|}
\hline Primary antibody & Secondary antibody \\
\hline Rabbit anti-hsp70 & Anti-rabbit IR 680 \\
(SPA-812 Stressgen) & (Molecular Probes) \\
Rat anti-hsp70 & Anti-rat IR800 \\
(SPA-815 Stressgen) & (Jackson ImmunoResearch) \\
Rabbit anti-hsp70 & Anti-rabbit IR800 \\
(EnVirtue Biotech Inc) & (Molecular Probes) \\
Mouse anti-hsc70 & Anti-mouse IR680 \\
(MA3-006, Biogen) & (Molecular Probes) \\
Rat anti-hsp90 & Anti-rat IR800 \\
(SPA-840 Stressgen) & (Jackson ImmunoResearch) \\
\hline
\end{tabular}


gel. The calibrant for each gel was normalized, and all other values were multiplied by this factor to allow comparison of intensities between gels.

Single polyp assessment. To validate that the techniques would work on true single coral polyp preparations, rather than pooled samples (as above), the optimized protocol (Technique v) was utilized in a standard heat-stress study (e.g. Brown et al. 2002). Coral explants were maintained at $26.5^{\circ} \mathrm{C}$ in the coral microcosm at the Virginia Institute of Marine Science. The coral reef microcosm is a $600 \mathrm{l}$, self-contained, closed-flow loop system using an algal scrubber to maintain water quality after Adey \& Loveland (1998). Daily maintenance included checking and adjusting temperature, salinity, water levels, $\mathrm{pH}$ and $\mathrm{CaCO}_{3}$. Four coral colonies were maintained in this system, and immediately before heat shock, 2 single coral polyps were removed from each of the test coral colonies. Thereafter, the same coral colonies were thermally shocked $\left(+4 \pm 0.1^{\circ} \mathrm{C}\right)$ for $30 \mathrm{~min}$, and 2 single polyps were again removed from the colonies. Coral polyps ( $\mathrm{n}=16$; 8 control, 8 heat shocked) were then individually processed using Technique $\mathrm{v}$, western blotting was performed simultaneously, using the hsp70 and hsp90 antibodies, and hsp concentration was quantified.

Validation. To ensure the validity of the methodology and results, 2 further control experiments were performed. Firstly, to ensure that the optimized protein purification technique was able to precipitate the target proteins (hsps), unstressed coral polyps were spiked with a known concentration (250 pg) of hsp70 calibrant and subjected to the sample-handling procedures described above. The polyps were then assayed for hsp content, pre- and post-spiking. To ensure that coral mucus and the surrounding seawater (and microflora) were not contaminating sources of hsp content, the protein from $3 \mathrm{ml}$ of mucus and $10 \mathrm{ml}$ of seawater were precipitated using Technique $\mathrm{v}$, and $5 \mathrm{\mu g}$ of protein from each source was probed for hsp content via western blotting.

\section{RESULTS}

\section{Protein concentration estimation}

The newly described technique for protein estimation using Commassie blue staining and detection, and the subsequent quantification with the Odyssey System, demonstrated that a solution containing as little as $6.25 \mu \mathrm{g} \mathrm{ml}^{-1}$ of protein (12.5 $\mathrm{ng}$ total protein) could be reliably assessed (Fig. 1a). The relationship between protein concentration and scanned intensity was linear over the 3 log range of protein concentration assessed (Fig. 1b).

\section{Polyp preparations}

Each technique for protein recovery from mock single coral polyps was assessed in relation to time of preparation and yield of protein. The best method, in regard to time, clarity of SDS-PAGE and yield was achieved through using Technique v (Table 2), followed by Technique iii. The technique of Downs et al. (2002) resulted in a moderate recovery of protein, but direct comparison of the yield could not be achieved because of the different initial polyp preparation (liquid nitrogen and sonication [Downs] versus Laemmli sample buffer and grinding and
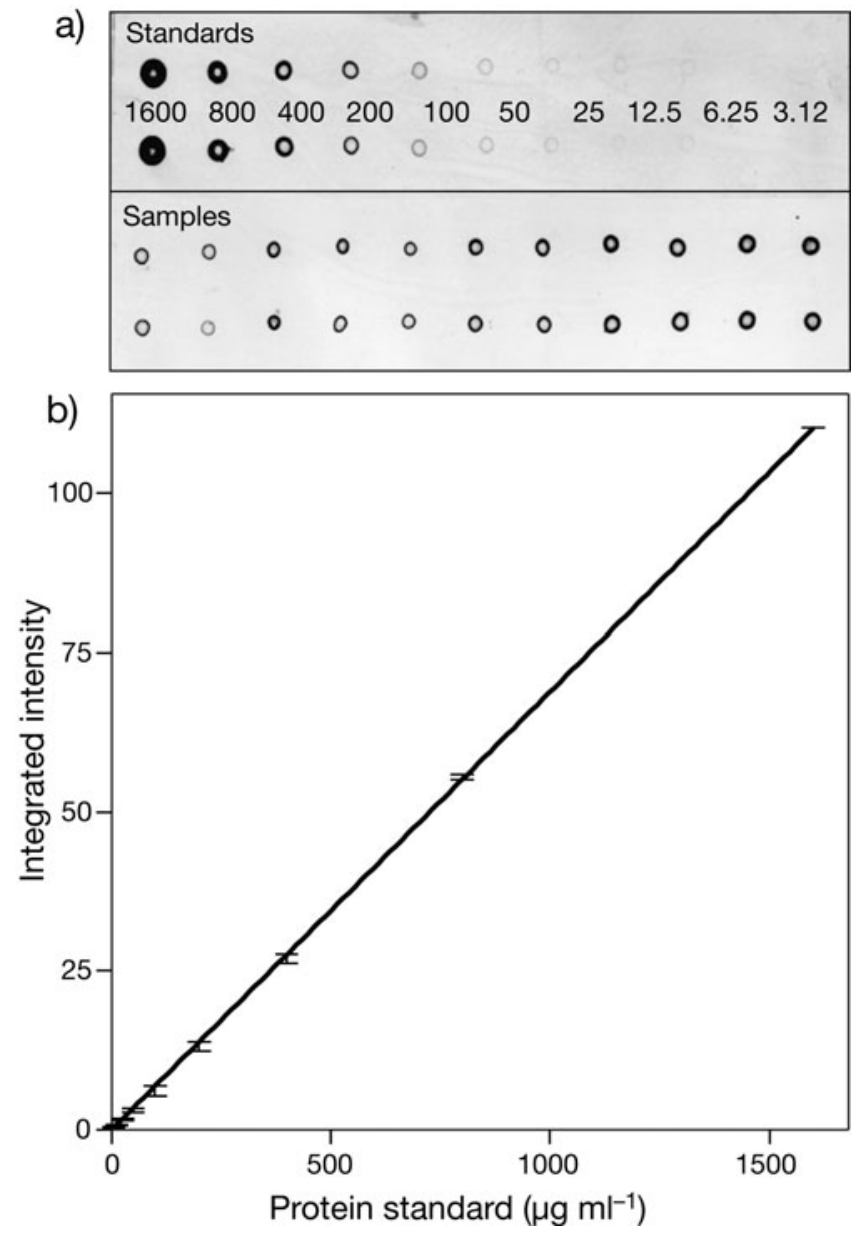

Fig. 1. (a) Scanned image of a Coomassie-stained polyvinylidene difluoride (PVDF) blot of protein standards and coral polyp samples (in duplicate); $2 \mu$ of protein standards and polyp homogenates were pipetted onto PVDF and stained with Coomassie blue. The de-stained PVDF was allowed to dry, placed face down on the surface of the Odyssey Infrared Imaging System (LI-COR), and scanned in the $700 \mathrm{~nm}$ channel with a $0.00 \mathrm{~mm}$ focus offset at $84 \mu \mathrm{m}$ pixel $^{-1}$ resolution. Total protein concentration of the polyps was estimated against the protein standards. (b) Relationship between scanned intensity and protein standards demonstrates the linear range of detection using Coomassie blue. Error bars = standard errors of the mean 


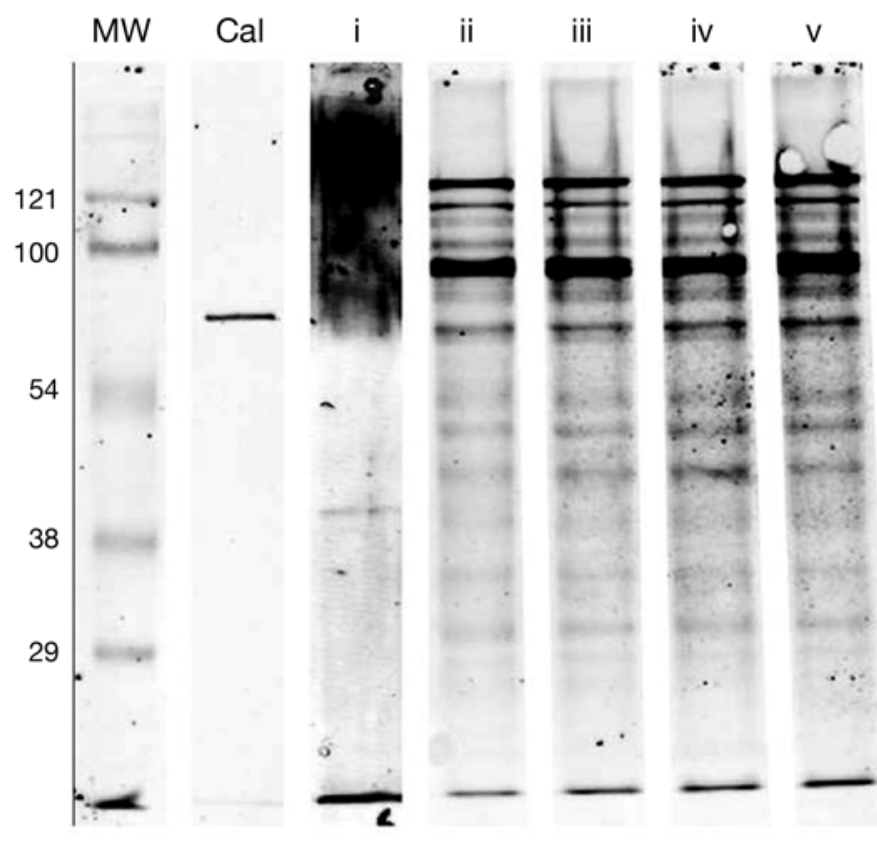

Fig. 2. Colloidal gold protein profiles of individual coral polyps processed by 5 different methods; $5 \mu$ of total protein were added to each lane (i to $\mathrm{v}$ ) representing the polyp processing methods (Techniques i to v) from Table 2, respectively. Molecular weights of re-stained, broad-range molecular weight markers (MW) are indicated on the left in $\mathrm{kDa}$; the adjacent lane is $100 \mathrm{ng}$ of the hsp70 calibrant (Cal)

boiling). The SDS-PAGE profiles demonstrated considerable smearing when the polyp homogenates were prepared by Technique i, which prohibited protein resolution (Fig. 2). The 4 remaining techniques displayed a similar protein resolution profile, with protein bands appearing sharp and in similar ratios between techniques. Therefore, due to the similarity in total protein resolution, faster polyp preparation time, and the increased total protein recovery, Technique $\mathrm{v}$ was used throughout.

\section{Antibody assessment for hsp quantification}

Polyp preparations purified by Technique $\mathrm{v}$ were used to assess the various anti-hsp/hsc antibodies (Table 3) that have been previously utilized in coral hsp studies. Only anti-hsp70 and anti-hsp90 (Stressgen) displayed consistently high resolution reactivity with proteins at 70 and $90 \mathrm{kDa}$, respectively, in heatstressed samples (Fig. 3). No reactivity was seen with the anti-hsc70 (Stressgen), or the Biogen antibody (anti-hsp70), and no specificity was observed with the hsp antibody from EnVirtue Biotech.

The dynamic range of hsp70 and hsp90 detection, via western blotting, using the Odyssey System was determined to be from $5 \mathrm{pg}$ to $100 \mathrm{ng}$ (Fig. 4) and from $50 \mathrm{pg}$ to $100 \mathrm{ng}$ (data not shown), respectively. Further, over the

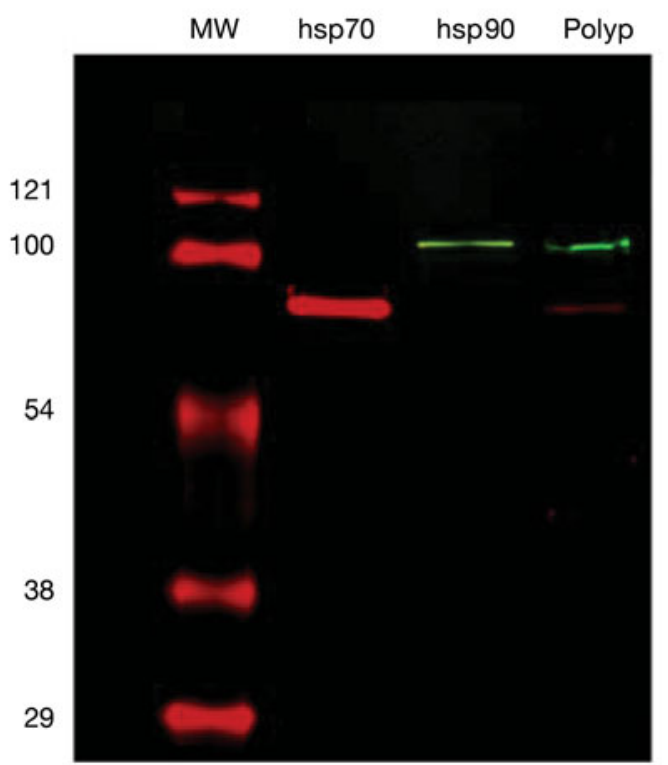

Fig. 3. Simultaneous detection of hsp70 and hsp90 demonstrated via western blotting, using the Odyssey Infrared Imaging System (Li-COR); $5 \mu \mathrm{g}$ of thermally shocked coral polyp homogenate were added to a lane of an SDS-PAGE gel and assessed by western blot, utilizing the $700 \mathrm{~nm}$ (red: hsp70) and the $800 \mathrm{~nm}$ (green: hsp90) channels of the Odyssey System. The single polyp lane (polyp) demonstrates the expression of both hsp forms. The molecular weight standards (MW) are given on the left in $\mathrm{kDa}$.

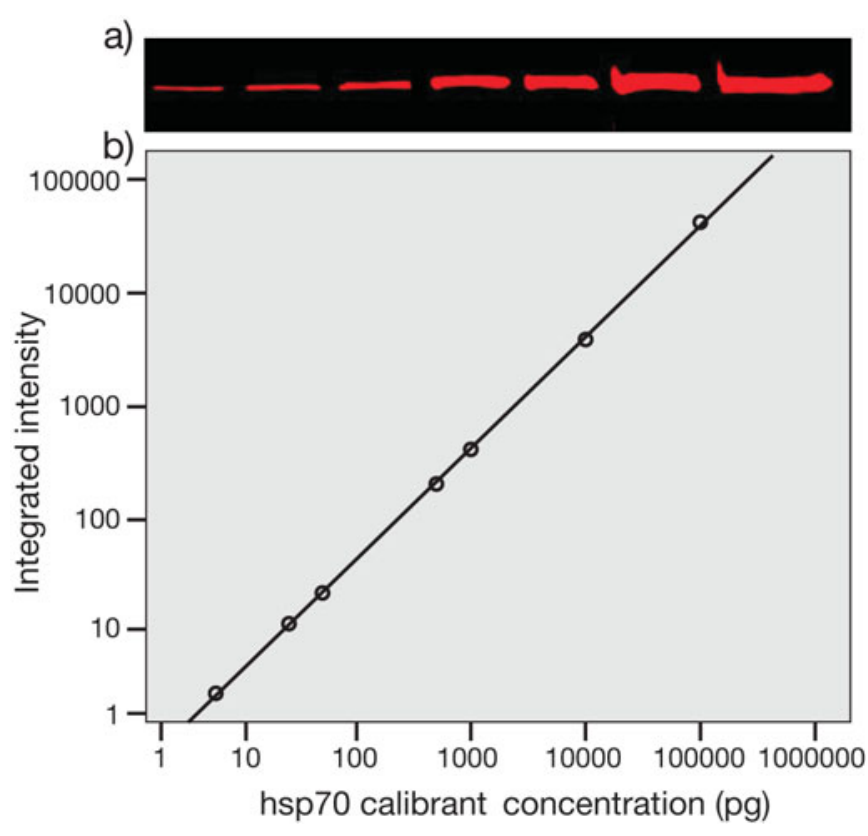

Fig. 4. Relationship between protein concentration of the hsp70 calibrant and integrated intensity. (a) Various concentrations of a hsp70 calibrant were added to a SDSPAGE gel and assessed via western blotting. (b) There was a linear relationship between protein concentration and signal intensity 
assessed protein range, there was a linear relationship between protein concentration and scanned intensity. This relationship allowed for a single calibrant concentration to be added to the gels to calculate hsp concentration in experimental samples.

To assess the validity of the sampling and processing techniques for assessing hsp70 or hsp90 concentrations in individual coral polyps, a heat-stress experiment was conducted. Single coral polyps sampled from colonies before and after thermal stress resolved a significant difference in the expression of hsp70 between the treatment groups $(p<0.01)$, while no significance was observed with hsp90 ( $\mathrm{p}>0.5$; Student's $t$-test; Fig. 5). The average protein yield from individually sampled coral polyps was $44 \pm 12 \mu \mathrm{g}(\mathrm{n}=16)$.

\section{Validation}

The spiking of a known concentration of hsp70 calibrant into coral polyps $(\mathrm{n}=5)$ resulted in a mean recovery of $93.7 \pm 3.4 \%$. No detectable hsp content was observed in either the mucus or the surrounding seawater, suggesting that their combined contribution to the quantifiable hsp concentration was below our detection limit.

\section{DISCUSSION}

The study of stress protein expression in corals has been subject to many limitations, including destructive sampling techniques, excessive sample handling resulting in protein degradation, and poor western blot resolution. The present study introduces novel techniques for sample acquisition, polyp processing and quantification, which resolve many of these problems. Researchers should consider the potential ecological advantages of these techniques for the assessment of coral health. Previous studies have utilized large pieces of coral tissue per sample (Table 1), and the laborious processing requirements associated with these large samples have made it difficult to gain a snap shot of coral health from field-derived samples. In addition, localized damage to the colony resulting from the non-surgical excision of tissue, for example, with a hammer and chisel, may lead to infection or further degradation of adjacent fragmented coral. In contrast, our technique utilized approximately $12 \mathrm{~mm}^{3}$ of coral tissue per sample, which is approximately 50 to 1000 times less than cited in previously published reports (Table 1), and permitted coral recovery and survival for $>2$ yr following the cessation of polyp sampling. Thus, if small sample volumes are required (e.g. western blotting), researchers no longer have to harvest such large samples from the species they wish to study. While the present study focused on polyps of Montastraea annularis, we believe the sampling methodology could potentially be applied to other coral species. For those corals with large polyp sizes the sampling tool described could still be used, as the same size of sampling bore would theoretically recover a similar amount of protein. The same is true for coral with smaller polyps than $M$. annularis, where one could either use the tool as described, thus sampling numerous polyps, or, alternatively, by replacing the
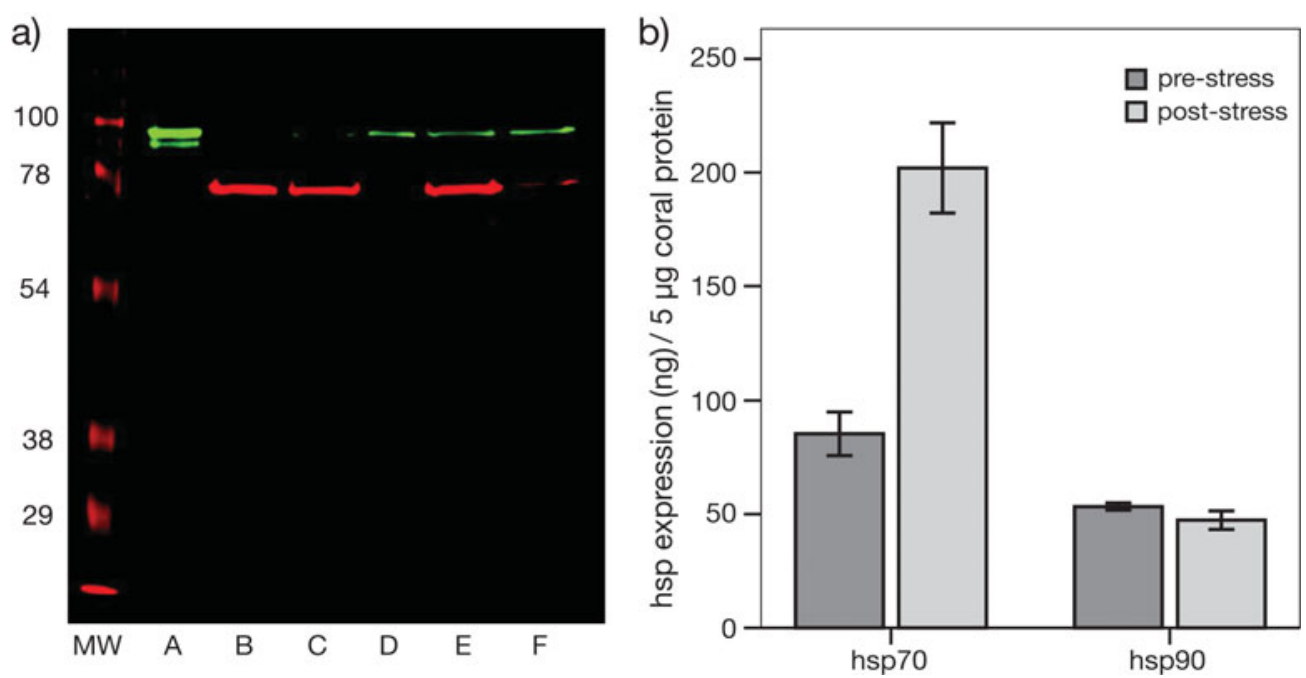

Fig. 5. (a) Expression of heat shock protein (hsp) between thermally shocked ( $\left.+4^{\circ} \mathrm{C} \pm 0.1\right)(\mathrm{Lanes} \mathrm{C}$ and E) and pre-stressed coral polyp samples (Lanes D and F). Coral colonies $(\mathrm{n}=4)$ were subjected to thermal shock and the expression of hsp70 and hsp90 was measured via western blotting. Lane A: hsp90 standard; Lane B: hsp70 standard; MW: molecular weight standard in kDa provided on the left. (b) Polyps demonstrated an elevated expression of hsp70 in relation to heat stress, while no significant difference in expression was observed with hsp90. Means \pm SEM 
biopsy needle with one of a smaller bore size, which would allow for individual polyp collection similar to that in the present study. However, it is currently unknown if sufficient protein would be recoverable at smaller volumes than those described here.

In order to accurately assess the recovery of total protein from the sampling techniques, a highly sensitive and rapid total protein quantification technique was required. Our technique, based on the original protocol described by Ghosh et al. (1988), provides for this rapid and quantitative analysis even in the presence of substances that would normally interfere with protein estimation (e.g. SDS). Further, the technique only required $4 \mu \mathrm{l}$ of the sample $(2 \times 2 \mu$ duplicates $)$, had a sensitivity of $3.12 \mu \mathrm{g} \mathrm{ml}^{-1}$ and a wide linear range (2500-fold), and the analysis of up to 40 samples is possible in $<2 \mathrm{~h}$. The main limitation of this technique is that samples must be loaded onto the membrane quickly, before it dries and becomes unable to bind protein.

Utilizing the widely applied technique for polyp preparation (Downs et al. 2000, Brown et al. 2002), we were unable to achieve the sensitivity or resolution required for analysis of hsp expression in single coral polyps. Thus, we examined alternative techniques that might allow the reliable recovery of proteins from contaminating substances, such as lipids and polysaccharides. A recently described polyp protein extraction technique utilized acetone precipitation to study hsp from 1 to $3 \mathrm{~cm}^{2}$ pieces of Agarcia agaricites and A. tenuifolia (Robbart 2002, Robbart et al. 2004). We also examined modifications of other methods that utilized protein precipitation, specifically those utilized in plant protein analysis, which are subject to poor SDS-PAGE resolution when contaminants are present (Saravanan \& Rose 2004, Carpentier et al. 2005). Technique v encompasses a method used widely in plant protein analysis and protein preparation for 2-dimensional SDS-PAGE, and allows the simultaneous precipitation of protein, while lipids and polysaccharides are retained in the fluid phase for easy extraction. Subsequent acetone washes of the precipitated protein removed any contaminants that were caught within the protein precipitate. This simplified technique allowed high protein recovery (94\%), high concentration of the protein sample and clear resolution in SDSPAGE (Figs. 2, $3 \&$ 5), while it reduced the processing time to approximately $5 \mathrm{~h}$, which is significantly shorter than in other methods (Table 2).

Following sample preparation, we were able to visualize hsp expression by utilizing traditional chromagen deposition-based methods, such as aminoethylcarbazol

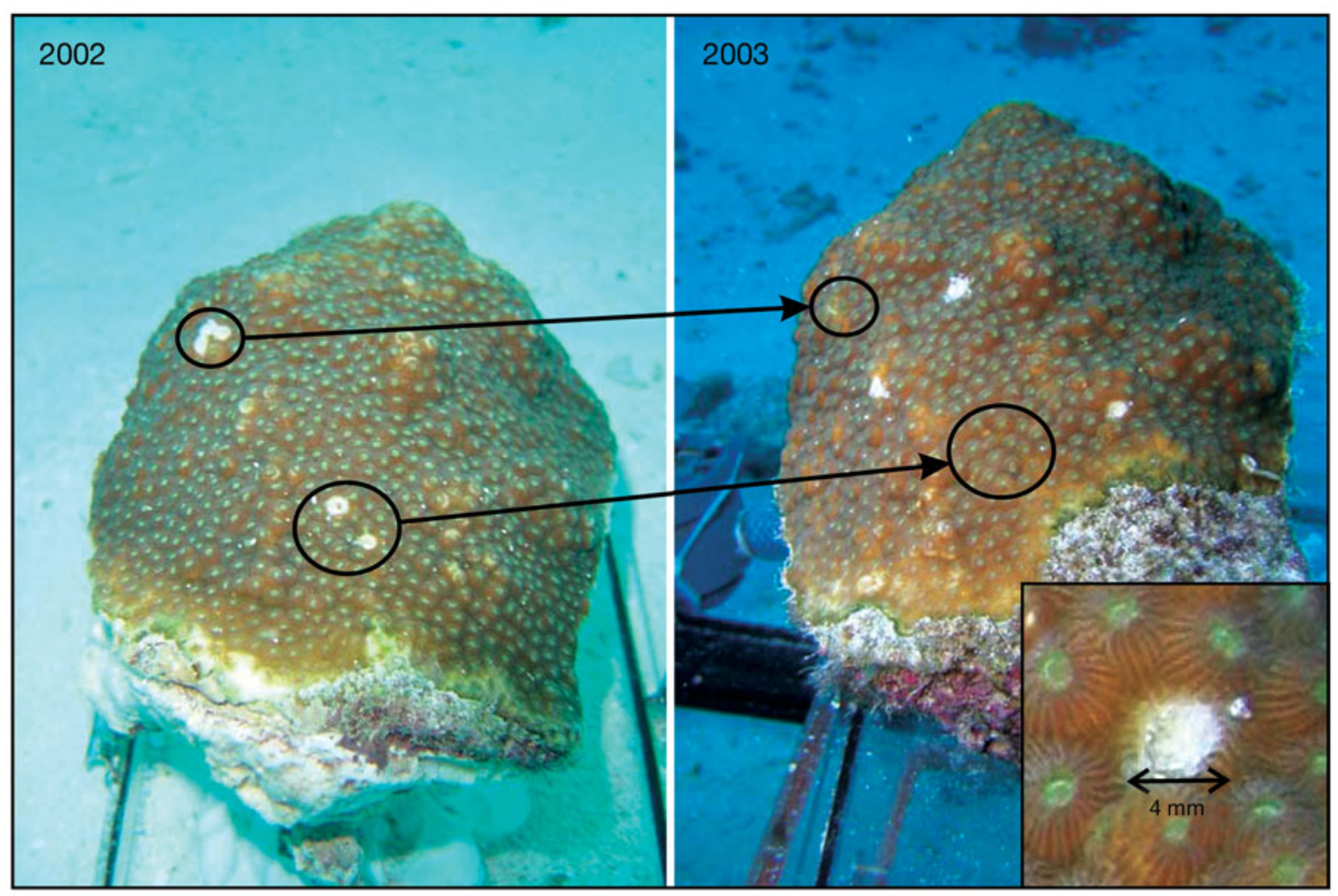

Fig. 6. Time series photograph of a coral colony from 2002 and 2003. Individual polyps were sampled from a coral head in 2002 and the same regions are highlighted on the 2003 photo, showing recovery of the coral (encircled areas). Inset: a magnification of a sampling site $1 \mathrm{~d}$ post-sampling where an individual coral polyp was excised from the coral colony 
and alkaline phosphatase (data not shown). However, the limited sensitivity and range of detection of these techniques (Bromage \& Kaattari 2007) precluded accurate densitometric analysis. The Odyssey System, based on laser imaging, utilizes fluorescent dyes in the 700 to $800 \mathrm{~nm}$ range, allowing dual detection of proteins over a wide concentration gradient. By using this system, we were able to assess both hsp70 and hsp90 expression in a single sample. The wide linear range of the system for detecting hsp70 (5 pg to 50 ng; Fig. 4) allowed quantification of hsp70 from coral polyps that ranged from 8.75

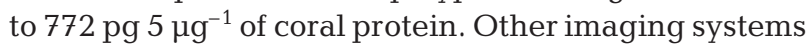
utilizing fluorescent dye technology should theoretically produce similar results to those obtained in the present study, while traditional chemiluminescent detection systems should also allow single target analysis. Further, as we were able to recover, on average, $44 \mu \mathrm{g}$ protein polyp $\mathrm{p}^{-1}$ and yet required only $5 \mu \mathrm{g}$ for analysis, sufficient protein was provided for multianalyte analyses.

Coral reefs are important for a wide range of studies. As instrumentation improves, sampling efficiency will likewise improve. An analysis by Carpenter et al. (2008) indicated that the extinction risk for many corals is now dangerously high. The authors further argued that the determining factors for whether or not the 'at risk corals' actually become extinct within this century are the severity of climate change, the extent of environment perturbations and the ability of corals to adapt. If corals do indeed fail to adapt, the functional loss of a reef's ecosystem would affect the geologic structure of reefs and coastal protection, and would also economically affect the hundreds of millions of people dependent on reef fish. What greater stimulus is there than that of the potential increase in coral reef extinction to develop the ability to monitor the health of a reef using minimally invasive procedures that can be carried out in situ, in near real time, at low cost, and using time series methodology? Given the small volume and relatively small amounts of recoverable protein from individual polyps, these novel methods may not necessarily be appropriate for all applications. Nonetheless, they do proffer the wherewithal for future coral studies to reduce the size of coral sampled and, at the same time, reduce the amount of sampling stress, as well as facilitate extended studies within the same coral colony.

Current collection methods can leave coral reefs damaged and vulnerable to disease and additional stress. For coral studies that require only low sample volume, or focus on time series data collections that are minimally invasive, this sampling method has many advantages (e.g. reduced damage to the underlying $\mathrm{CaCO}_{3}$ structure, no mechanical shock from hammer blows, etc.), and it has been used recently to successfully conduct time series sampling of coral colonies over 2 field seasons (authors' unpubl. data and Fig. 6).
The ability of a researcher to acquire numerous replicates from a single colony and to repeatedly sample the same coral over time will generate robust statistical analysis, leading to more effective study and management decisions. Additionally, coral reef systems could be routinely sampled while monitoring preand post-events of interest.

Acknowledgements. This research was funded by a grant from the National Oceanic and Atmospheric Administration's Undersea Research Center at the University of North Carolina at Wilmington pursuant to NOAA Award Number NA03OAR4300088. We thank Jo Gascoigne, Janet Nestlérode, Kristen Delano Walter and Beth Hinchey Malloy for field support as aquanauts; Lauren Batte Lugo, Randy Cutter and Danny Gouge for topside diving support; and the staff of the NOAA NURC Aquarius underwater habitat, especially former director Dr. Steven Miller, for excellent and safe field operations. This paper is Contribution No. 2980 of the Virginia Institute of Marine Science, The College of William and Mary.

\section{LITERATURE CITED}

Achituv Y, Ben-Zion M, Mizrahi L (1994) Carbohydrate, lipid, and protein composition of zooxanthellae and animal fractions of the coral Pocillopora damicornis exposed to ammonium enrichment. Pac Sci 48:224-233

Adey WH, Loveland K (1998) Dynamic aquaria: building living ecosystems, 2nd edn. Academic Press, New York

Black NA, Voellmy R, Szmant AM (1995) Heat shock protein induction in Montastraea faveolata and Aiptasia pallida exposed to elevated temperatures. Biol Bull 188:234-240

Bromage ES, Kaattari SL (2007) Simultaneous quantitative analysis of multiple protein species within a single sample using standard scanning densitometry. J Immunol Methods 323:109-113

$>$ Brown BE, Downs CA, Dunne RP, Gibb SW (2002) Exploring the basis of thermotolerance in the reef coral Goniastrea aspera. Mar Ecol Prog Ser 242:119-129

Buckley BA, Hofmann GE (2002) Thermal acclimation changes DNA-binding activity of heat shock factor 1 (HSF1) in the goby Gillichthys mirabilis: implications for plasticity in the heat-shock response in natural populations. J Exp Biol 205:3231-3240

Bythell JC, Sharp VA, Miller D, Brown BE (1995) A novel environmentally-regulated $33 \mathrm{kDa}$ protein from tropical and temperate cnidarian zooxanthellae. J Therm Biol 20: $15-22$

Carpenter KE, Abrar M, Aeby G, Aronson RB and others (2008) One-third of reef-building corals face elevated extinction risk from climate change and local impacts. Science 321:560-563

> Carpentier SC, Witters E, Laukens K, Deckers P, Swennen R, Panis B (2005) Preparation of protein extracts from recalcitrant plant tissues: an evaluation of different methods for two-dimensional gel electrophoresis analysis. Proteomics 5:2497-2507

Downs CA, Mueller E, Phillips S, Fauth JE, Woodley CM (2000) A molecular biomarker system for assessing the health of coral (Montastraea faveolata) during heat stress. Mar Biotechnol 2:533-544

> Downs CA, Fauth JE, Halas JC, Dustan P, Bemiss J, Woodley CM (2002) Oxidative stress and seasonal coral bleaching. Free Radic Biol Med 33:533-543

Downs CA, Woodley CM, Richmond RH, Lanning LL, Owen R 
(2005) Shifting the paradigm for coral reef 'health' assessment. Mar Pollut Bull 51:486-494

Ducklow HW, Mitchell R (1979) Composition of mucus released by coral reef coelenterates. Limnol Oceanogr 24: 706-714

Ellis RJ (1996) Stress proteins as molecular chaperones. In: van Eden W, Young DB (eds) Stress proteins in medicine. Marcel Dekker, New York

Gardner TA, Côte IM, Gill JA, Grant A, Watkinson AR (2003) Long-term region-wide declines in Caribbean corals. Science 301:958-960

Ghosh S, Gepstein S, Heikkila JJ, Dumbroff EB (1988) Use of a scanning densitometer or an ELISA plate reader for measurement of nanogram amounts of protein in crude extracts from biological tissues. Anal Biochem 169: 227-233

Harlow E, Lane D (1988). Appendix 1: electrophoresis. Antibodies: a laboratory manual. Cold Springs Harbor Laboratory Press, NY, p 635-659

Hoegh-Guldberg O (1999) Climate change, coral bleaching and the future of the world's coral reefs. Mar Freshw Res 50:839-866

Hoegh-Guldberg O (2003) Near- and long-term strategies for preserving coral reefs. In: Proceedings of the 5th international conference on environmental future. ETH, Zurich

> Hofmann GE (2005) Patterns of Hsp gene expression in ectothermic marine organisms on small to large biogeographic scales. Integr Comp Biol 45:247-255

Hughes TP, Baird AH, Bellwod DR, Card M and others (2003) Climate change, human impacts and the resilience of coral reefs. Science 301:929-933

Jackson JBC, Kirby MX, Berger WH, Bjorndal KA and others (2001) Historical overfishing and the recent collapse of coastal ecosystems. Science 293:629-637

Knowlton N (2001) The future of coral reefs. Proc Natl Acad Sci USA 98:5419-5425

Krupp DA (1985) An immunochemical study of the mucus from the solitary coral Fungia scutaria (Scleractinia, Fungiidae). Bull Mar Sci 36:163-176

Laemmli UK (1970) Cleavage of structural proteins during the assembly of the head of bacteriophage T4. Nature 227: 680-685

Lindquist S (1986) The heat-shock response. Annu Rev Biochem 55:1151-1191

Miller KJ, Ayre DJ (2004) The role of sexual and asexual reproduction in structuring high latitude populations of the reef coral Pocillopora damicornis. Heredity 92: 557-568

Editorial responsibility: Charles Birkeland,

Honolulu, Hawaii, USA
Miller D, Brown BE, Sharp VA, Nganro N (1992) Changes in the expression of soluble proteins extracted from the symbiotic anemone Anemonia viridis accompany bleaching induced by hyperthermia and metal stressors. J Therm Biol 17:217-223

Nystrom M, Folke C, Moberg F (2000) Coral reef disturbance and resilience in a human-dominated environment. Trends Ecol Evol 15:413-417

Oku H, Yamashiro H, Onaga K, Sakai K, Iwasaki H (2003) Seasonal changes in the content and composition of lipids in the coral Goniastrea aspera. Coral Reefs 22:83-85

Pandolfi JM, Bradbury RH, Sala E, Hughes TP and others (2003) Global trajectories of the long-term decline of coral reef ecosystems. Science 301:955-958

Robbart ML (2002) Population dynamics and differential heat shock protein expression in two Caribbean scleractinian corals, Agaricia agaricites and A. tenuifolia. MSc thesis, Smith College, Northampton, MA

Robbart ML, Peckol P, Scordilis SP, Curran HA, Brown-Saracino J (2004) Population recovery and differential heat shock protein expression for the corals Agaricia agaricites and A. tenuifolia in Belize. Mar Ecol Prog Ser 283:151-160

Rowan R, Knowlton N, Baker A, Jara J (1997) Landscape ecology of algal symbionts creates variation in episodes of coral bleaching. Nature 388:265-269

Saravanan RS, Rose JK (2004) A critical evaluation of sample extraction techniques for enhanced proteomic analysis of recalcitrant plant tissues. Proteomics 4:2522-2532

Sharp VA, Miller D, Bythell JC, Brown BE (1994) Expression of low molecular weight HSP70 related polypeptides from the symbiotic sea anemone Anemonia viridis Forskall in response to heat shock. J Exp Mar Biol Ecol 179:179-193

Sharp VA, Brown BE, Miller D (1997) Heat shock protein (hsp 70) expression in the tropical reef coral Goniopora djiboutiensis. J Therm Biol 22:11-19

Toller WW, Rowan R, Knowlton N (2001) Zooxanthellae of the Montastrea annularis species complex: patterns of distribution of four taxa of Symbiodinium on different reefs and across depths. Biol Bull 201:348-359

Wilkinson C, Linden O, Cesar H, Hodgson G, Rubens J, Strong AE (1999) Ecological and socioeconomic impacts of 1998 coral mortality in the Indian Ocean: An ENSO impact and a warning of future change? Ambio 28:188-196

Yamashiro H, Oku H, Higa H, Chinen I, Sakai K (1999) Composition of lipids, fatty acids and sterols in Okinawan corals. Comp Biochem Physiol B 122:397-407

Submitted: April 12, 2007; Accepted: November 4, 2008

Proofs received from author(s): February 2, 2009 